DOI: https://doi.org/10.31392/NZ-npu-143.2019.29

УДК 378.011.03-051:796]:908

\title{
Kravets Michael
}

\section{PECULARITIES OF THE FUTURE PHYSICAL EDUCATION TEACHERS' TRAINING TO THE LOCAL ACTIVITIES}

The article analyzes various aspects of the professional training of future teachers of physical culture, discloses the essence of the concept of "competence approach". It is noted that the main directions of the implementation of the competence approach in the preparation of future teachers of physical culture to local lore activities include: didactic, professional, creative, reflexive. On the basis of the analysis of scientific and methodological sources it was determined that local studies of future teachers of physical culture on the basis of a competent approach is a purposeful research and research activity whose purpose is to expand and deepen knowledge, skills and abilities, to develop amateur and creative abilities, to satisfy interest in the subject and to ensure the development of physical and mental health.

The methodical system of vocational training of future teachers of physical culture is determined on the basis of a competency approach, which is complex, open and dynamic. The professional competence of the physical education teacher consists of competences that are observed, measured and purposefully formed in the process of education.

The article substantiates the methodological approaches in local studies, such as anthropological, axiological, systemic, cultural, ethnopedagogical. The structure of local lore knowledge is revealed: empirical (concepts, terms, facts surrounding the reality), theoretical (laws, theories, hypotheses).

Keywords: professional training of future teachers of physical culture, competence approach, organization of local lore activity, creative abilities, educational process, modern pedagogical technologies.

Under current conditions, the need to develop new conceptual approaches to the training of specialists and future teachers of physical culture, in particular. The issue of providing future physical education teachers with relevant basic vocational education to local lore activities is based on the principles of a competent approach.

According to the National Strategy for the Development of Education of Ukraine for 2012-2021, the Law of Ukraine "On Education" (2017), the Law of Ukraine "On Higher Education" (2014) and other normative documents, the orientation of professional pedagogical education argues the use of a competent approach, which testifies the necessity of creating conditions for effective preparation of future teachers of physical culture.

According to $\mathrm{V}$. Kremin, an important place is placed on the local lore of the individual, the essence of which is love of the native land, patriotism, interest and creative attitude to local lore work, the need for obtaining regional knowledge through studying the historical past and respectful attitude to the inheritance, folk traditions and customs, providing a competent approach in teaching [10].

Different aspects of the training of future teachers of physical education have devoted their work to many scientists. So, L. Sushchenko, S. Fil, B. Shiyan studied theoretical and methodological aspects of the preparation and application of information 
technologies studied G. Genseruk, interdisciplinary relations - L. Deminskaya, the role of research - L. Zavadskaya, preparation for implementation interdisciplinary connections in the process of physical education - O. Kruglyak, pedagogical conditions for the provision of multi-level professional training - P. Yefimenko, formation of readiness for professional activity $-M$. Danilko and the pedagogical orientation of the teacher of physical culture - O. Yemets, Ped Gogic skill of the teacher of physical culture was studied by M. Krychfalushy, O. Petunin.

The question of competence approach is disclosed in the works of B. Anan'ev [1], I. Zimnaya [6], O. Leontiev [12], O. Pometun [14], S. Rubinstein [17], A. Khutorskogo [20]; V. Samoilenko, O. Topuzov, L. Vishnikina, I. Dibrovy [2]. The main idea of a competent approach is that the result of education is not individual knowledge, skills and competences, and the competence by which future specialists meet modern labor market demands, successfully perform complex tasks, realize their own professional potential.

Therefore, in view of the main aspects of the analyzed developments, there was a need to study and systematize the acquired scientific and methodological experience of preparing future teachers of physical culture for local lore activities based on the competency approach.

The purpose of the paper is to determine the peculiarities of local lore activities of future teachers of physical culture on the basis of a competent approach.

Scientists in the definition of the concept of "competence approach" distinguish certain differences. The concept of "competence approach" is defined as: a set of general principles for determining the goals of education, the selection of educational content, the organization of educational process and the assessment of educational outcomes (O. Lebedev); as "the focus of the educational process on the formation and development of the key (basic, basic) and substantive competencies of the individual" (V. Khiminets) [11].

Essential content of the concept of "competence approach" O. Pometune understands as the focus of the educational process on the formation of key (basic, basic) and substantive competencies of the individual [15].

L. Yelagina argues that as a goal in implementing a competent approach in vocational education, in this case, the formation of a competent specialist who has a culture of professional activity. L. Elagina notes that the competent approach allows to select the content of vocational education in accordance with the needs of the developing person and at the same time guides him to the innovative experience of successful professional activities in a particular field. The author argues that the methodological basis for the implementation of the competence approach in vocational education comes from the principles: variability of education; the concentration of education on the development and self-development of the individual; the combination of autonomy with collective and group forms of education; the unstable dynamic balance of the educational process as a source of development of the relationship of personality, education and profession [4].

According to O. Dubaseniuk, O. Voznyuk's competence approach reflects the integral manifestation of professionalism, which combines the elements of professional and general culture, the experience of pedagogical activity and pedagogical creativity, which is specified in a certain system of knowledge, skills, readiness for professional decision of pedagogical tasks and problems [3]. 
A. Sambrat points out that the competence approach is education for life, successful socialization in society and personal development on the basis of students' acquisition of socially meaningful skills (competences); evaluation to enable the student to plan his or her educational results and improve them in the process of constant selfevaluation; various forms of organization of independent, meaningful activity of students on the basis of their own motivation and responsibility for the result; matrix management system, delegation of authority, attraction of people from the external environment to the management of education and evaluation of activity, freedom of the teacher in choosing the means of inculcating students social priorities (competences) [18].

L. Yelagina points out that the competence approach involves a priority orientation towards the goal - education vectors: ability to learn, self-determination (selfdetermination), self-actualization, socialization and individual development [4].

Considering that the competence approach involves not only knowledge, skills and abilities of the student, but also the acquisition of professional experience, we consider him one of the leading methodological approaches to training future teachers of physical culture in the organization of regional studies of students.

As L. Ivanova points out - "the competence approach implies a clear orientation towards the future, which manifests itself in the possibility of building its education, taking into account the success in personal and professional activities". The author believes that "the competent approach requires the use of active forms of learning, the use of modern technologies, so knowledge can not be given ten years ahead, we must learn to study and retrain and the main criterion of training is to regard readiness for independent activity at the next stage (either in study, or in life)" [8].

The application of a competent approach to the training of graduates of an OHS involves the achievement of an integrated end result of education, which can be regarded as the formation of a graduate of key [20] and professional competencies [5; 9] as a unity of generalized knowledge and skills, universal ability and readiness for solving large groups of tasks - from personal to social, professional and special professional competencies, which determine the ownership of own professional activity at a sufficiently high level, readiness for innovations in the professional field. This requires the development of a qualitatively new methodical system that takes into account the mutual influence of internal and external factors on its development and orientation on the acquisition of the future teacher of physical education of the necessary competences and further self-development in professional activity.

The effectiveness of the process of training future teachers of physical culture depends to a large extent on properly selected technology of conducting local lore activities that contribute to the growth of cognitive motivation, interest and activity of students, as a consequence - the formation of individual cognitive experience.

Opinions on the introduction of a competent approach in the field of higher education in foreign countries make it possible to outline the ways of its adoption in the educational process of Ukraine. This approach to the training of a future teacher serves as a methodological program oriented towards the predicted achievement of a qualitative educational outcomes, the generation of promising ideas and factors under its influence; on the study of local lore aspects of pedagogical activity, development, implementation of creative ideas and pedagogical technologies. The main directions of its use in the preparation of future teachers of physical culture to the local lore are: 
didactic - aimed at the formation of knowledge and skills in regional studies; professional - definition of ability to work through finding out the level of motivation and readiness for this type of work in non-standard conditions of local lore activities; creative - research of the level of professionalism, innovative potential; reflexive - the study of the sphere of self-awareness student-athlete and his autonomy in local studies [16].

We are impressed by the author's concept of $O$. Tymets, according to which the professional competence of the future teacher is an integral characteristic of personal formation (the presence of learning motivation and value orientations) and professional activity, which is related to the ability to use the complex of professional knowledge, abilities and skills and the possession of common intelligence actions (analysis, synthesis, comparison, generalization, etc.) and their specification on the material of fundamental and special disciplines; Ability to conduct research on selected issues [19].

The concept of "competence" is not the sum of knowledge, skills and skills, because it covers the knowledge, operational-technological, value-motivational aspects that are characteristic of the activity [13].

In the process of preparing future teachers, the competence approach is to develop the ability to manipulate information, design their activities, apply creatively the acquired knowledge and experience in different pedagogical situations.

Consequently, the competence-oriented methodical system of professional training of the teacher of physical culture should be functional, it should take into account the nature of the social order for the training of highly skilled teachers of physical culture, goals, principles and content of students' professional training, and must contain elements of planning, control, analysis and correction of the pedagogical process (feedback). If we talk about the professional training of future teachers of physical culture, then in the competence approach, the connection of components of the methodical system is different from simple hierarchical subordination from the top down. The scheme is complex, open, dynamic, by the results of intermediate control can be supplemented with new components and components. Competency approach allows to imagine the professional competence of the teacher of physical culture, which consists of a number of competencies that can be objectively monitored, with a certain accuracy measured and purposefully formed in the educational and professional process [7].

A competent approach in the activities of future teachers of physical culture, engaged in local lore activities, is realized through professionally directed educational and cognitive activities, which involves involving students in an independent search for new knowledge, mastering new ways of activity, using various forms of research work.

We believe that the overwhelming professional competences of future teachers of physical culture for the implementation of regional studies are the following: formation of knowledge and skills, providing organizational activities, taking into account the biological rhythms and age characteristics of students, team management, logistics, compliance with safety rules, conservation and health promotion of students, work planning, research activities.

The prognostic trends of further development and improvement of local lore activities are determined by poly-facet [10]. In particular, integration, which consists in enriching the connections of regional studies with other sciences, especially with geography, history, economics, culturology, sociology. The development of local lore is associated with the development of leading categories; detection of rules; the 
nomination of hypotheses, ideas; establishment of scientific facts; studying and comprehension of forms and methods of local lore work; definition of the laws of geographical science as a basis of regional studies; extension of its subject.

Theoretical and methodological trends include the improvement of the scientific apparatus of regional studies. Further improvement and substantiation of the methodological principles of regional studies, in particular, enrichment of the leading methodological approaches (anthropological, axiological, systemic, activity-personal, cultural, ethnopedagogical, historical, etc.); improvement of the structure of regional knowledge, which forms the basis of theoretical training: 1) empirical knowledge (concepts and terms - natural components, physical and geographical, socioeconomic, socio-cultural phenomena, facts of the surrounding reality); 2) theoretical knowledge (laws, theories, hypotheses - the interconnection of natural objects, processes, phenomena, their structural characteristics, features and patterns of development).

It should be noted that the creation of a coordination system for the training of future teacher-subjects in order to ensure their professional competence, which activates the introduction of a competent approach to local lore education.

Conclusions. Consequently, the regional studies of the future teachers of physical culture on the basis of a competent approach is defined as purposeful research and development, whose purpose is to expand and deepen knowledge, skills and abilities, to develop amateur and creative abilities, to satisfy interest in the subject and to ensure the development of physical and mental health. Therefore, the organization of regional studies of future teachers of physical culture on the basis of a competent approach should be determined by a set of general principles, the formulation of the objectives of this type of activity, the organization of the educational process with modern pedagogical technologies.

\section{Використана література:}

1. Ананьев Б. Г. О проблемах современного человекознания. Санкт-Петербург, 2001. 272 с.

2. Дидактика географії: [монографія] / В. М. Самойленко, О. М. Топузов, Л. П. Вішнікіна, І. О. Діброва. Київ : Ніка-Центр, 2013. 570 с.

3. Дубасенюк О. А. Концептуальні підходи до професійно-педагогічної

4. Елагина Л. В. Формирование культуры профессиональной деятельности будущего специалиста на основе компетентностного подхода (методология, теория, практика) [текст] : автореф. дис. ... док. пед. н. : 13.00 .08 [спец. Теория и методика профессионального образования]. Челябинск, 2008. $55 \mathrm{c}$.

5. Життєва компетентність особистості : наук.-метод. посіб. / за ред. Л. В. Сохань, І. Г. Єрмакова та ін. Київ : Богдана, 2003. 520 с.

6. Зимняя И. А. Ключевые компетентности как результативно-целевая основа компетентностного подхода в образовании: Авторская версия. Москва : Исслед. центр проблем кач-ва подгот. спец., 2004. $110 \mathrm{c}$.

7. Іваній І. Компетентнісний підхід до професійної підготовки вчителя фізичної культури. Фізичне виховання, спорт і культура здоров’я у сучасному суспільстві : збірник наукових праць. № 1 (21). 2013. C. 43-47.

8. Іванова Л. І. Підготовка майбугніх учителів фізичної культури до фізкультурно-оздоровчої роботи з учнями загальноосвітніх навчальних закладів : автореф. дис. ... канд. пед. наук спец. : 13.00.04 “Теорія та методика професійної освіти” / Л. І. Іванова. Київ, 2006. 24 с.

9. Комплекс нормативних документів для розроблення складових систем галузевих стандартів вищої освіти / за заг. ред. В. Д. Шинкарука ; уклад. : Я. Я. Болюбаш, К. М. Левківський. Київ : МОН України, IITі3О, 2008. 24 с. 
10. Кремень В. Вітчизняне краєзнавство: стратегічні орієнтири сучасної освітньої парадигми. Краєзнавство. 2011. № 3. С. 10-15.

11. Лебедев О. Е. Компетентностный подход в образовании. Школьные технологии. 2004. № 5. С. 3-11.

12. Леонтьев А. Н. Деятельность. Сознание. Личность. Москва: Политиздат, 1975. 302 с.

13. Міхеєнко О. I. Теоретичні і методичні основи професійної підготовки майбутніх фахівців зі здоров'я людини до застосування здоров'язміцнювальних технологій : автореф. дис. ... док. пед. наук : 13.00 .04 / O. I. Міхеєнко. Тернопіль, 2016. 40 с.

14. Пометун О. I. Інтерактивні технології навчання: теорія, практика, досвід / О. І. Пометун, Л. В. Пироженко. Київ : АПН, 2002. 136 с.

15. Пометун О. Теорія і практика послідовної реалізації компетентнісного підходу в досвіді зарубіжних країн / О. Пометун // Компетентнісний підхід у сучасній освіті : світовий досвід та українські перспективи / під заг. ред. О. В. Овчарук. Київ : К.І.С., 2004. С. 16-25.

16. Рожі І. Г. Підготовка майбутніх учителів географії до краєзнавчо-туристської роботи на засадах компетентнісного підходу : дис. ... канд. пед. н. : 13.00.04 - теорія і методика професійної освіти ; наук. кер. О. В. Браславська. Умань : Уманський ДПУ імені Павла Тичини, 2018. 357 с.

17. Рубинштейн С. Л. Основы общей психологи [в 2-х т.] / С. Л. Рубинштейн ; сост. авт. коммент. : К. А. Абульханова-Славская, А. В. Брушлинский. Москва : Педагогіка, 1989. Т. 1. 488 с.

\section{References:}

1. Ananev B. G. O problemah sovremennogo chelovekoznaniya. Sankt-Peterburg, 2001. 272 s.

2. Dydaktyka heohrafii : [monohrafiia] /V. M. Samoilenko, O. M. Topuzov, L. P. Vishnikina, I. O. Dibrova. Kyiv : Nika-Tsentr, 2013. $570 \mathrm{~s}$.

3. Dubaseniuk O. A. Kontseptualni pidkhody do profesiino-pedahohichnoi

4. Elagina L. V. Formirovanie kultury professionalnoj deyatelnosti budushego specialista na osnove kompetentnostnogo podhoda (metodologiya, teoriya, praktika) [tekst] : avtoref. dis. ... dok. ped. nauk : 13.00.08 [spec. Teoriya i metodika professionalnogo obrazovaniya]. Chelyabinsk, 2008. $55 \mathrm{~s}$.

5. Zhyttieva kompetentnist osobystosti : nauk.-metod. posib. / za red. L. V. Sokhan, I. H. Yermakova ta in. Kyiv : Bohdana, 2003. $520 \mathrm{~s}$.

6. Zimnyaya I. A. Klyuchevye kompetentnosti kak rezultativno-celevaya osnova kompetentnostnogo podhoda v obrazovanii: Avtorskaya versiya. Moskva : Issled. centr problem kach-va podgot. spec., 2004. $110 \mathrm{~s}$.

7. Ivanii I. Kompetentnisnyi pidkhid do profesiinoi pidhotovky vchytelia fizychnoi kultury. Fizychne vykhovannia, sport i kultura zdorovia u suchasnomu suspilstvi : zbirnyk naukovykh prats. № 1 (21). 2013. S. 43-47.

8. Ivanova L. I. Pidhotovka maibutnikh uchyteliv fizychnoi kultury do fizkulturno-ozdorovchoi roboty z uchniamy zahalnoosvitnikh navchalnykh zakladiv : avtoref. dys. ... kand. ped. nauk spets. : 13.00.04 "Teoriia ta metodyka profesiinoi osvity" / L. I. Ivanova. Kyiv, 2006. 24 s.

9. Kompleks normatyvnykh dokumentiv dlia rozroblennia skladovykh system haluzevykh standartiv vyshchoi osvity / za zah. red. V. D. Shynkaruka ; uklad. : Ya. Ya. Boliubash, K. M. Levkivskyi. Kyiv : MON Ukrainy, IITiZO, 2008. $24 \mathrm{~s}$.

10. Kremen V. Vitchyzniane kraieznavstvo: stratehichni oriientyry suchasnoi osvitnoi paradyhmy. Kraieznavstvo. 2011. № 3. S. 10-15.

11. Lebedev O. E. Kompetentnostnyj podhod v obrazovanii. Shkolnye tehnologii. 2004. № 5. S. 3-11.

12. Leontev A. N. Deyatelnost. Soznanie. Lichnost. Moskva: Politizdat, 1975. $302 \mathrm{s.}$

13. Mikheienko O. I. Teoretychni i metodychni osnovy profesiinoi pidhotovky maibutnikh fakhivtsiv zi zdorov'ia liudyny do zastosuvannia zdorov'iazmitsniuvalnykh tekhnolohii : avtoref. dys. ... dok. ped. nauk : 13.00.04 / O. I. Mikheienko. Ternopil, 2016. $40 \mathrm{~s}$.

14. Pometun O. I. Interaktyvni tekhnolohii navchannia: teoriia, praktyka, dosvid /O. I. Pometun, L. V. Pyrozhenko. Kyiv: APN, 2002. 136 s.

15. Pometun O. Teoriia i praktyka poslidovnoi realizatsii kompetentnisnoho pidkhodu $\mathrm{v}$ dosvidi zarubizhnykh krain / O. Pometun // Kompetentnisnyi pidkhid u suchasnii osviti : svitovyi dosvid ta ukrainski perspektyvy / pid zah. red. O. V. Ovcharuk. Kyiv : K.I.S., 2004. S. 16-25.

16. Rozhi I. H. Pidhotovka maibutnikh uchyteliv heohrafii do kraieznavcho-turystskoi roboty na zasadakh kompetentnisnoho pidkhodu : dys. ... kand. ped. n. : 13.00.04 - teoriia i metodyka profesiinoi osvity ; nauk. ker. O. V. Braslavska. Uman : Umanskyi DPU imeni Pavla Tychyny, 2018. 357 s. 
17. Rubinshtejn S. L. Ocnovy obshej psihologi [v 2-h t.] / S. L. Rubinshtejn; sost. avt. komment. : K. A. Abulhanova-Slavskaya, A. V. Brushlinskij. Moskva : Pedagogika, 1989. T. 1. 488 c.

\section{КРАВЕЦЬ М. В. Особливості підготовки майбутніх вчителів фізичної культури до краєзнавчої діяльності.}

Проаналізовано різні аспекти професійної підготовки майбутніх учителів фізичної культури, розкрито сутнісний зміст поняття “компетентнісний підхід”. Визначено основні напрями реалізації компетентнісного підходу у підготовиі майбутніх учителів фізичної культури до краєзнавчої діяльності, такі як дидактичний, професійний, креативний, рефлексивний. На основі аналізу науково-методичних джерел визначено, щзо краєзнавча діяльність майбутніх учителів фізичної культури на основі компетентнісного підходу $\epsilon$ иілеспрямованою пошуково-дослідницькою діяльністю, метою якої $\epsilon$ розширення та поглиблення знань, уміннь і навичок, розвиток самодіяльності і творчих здібностей, інтересу до предмета й забезпечення фізичного і психічного здоров'я.

Визначено методичну систему професійної підготовки майбутніх учителів фізичної культури на основі компетентнісного підходу, яка є складною, відкритою і динамічною. Професійна компетентність учителя фізичної культури складається з компетенцій, які можуть бути об'єктивно спостережені, виміряні й иілеспрямовано сформовані в освітньопрофесійному проиесі.

У статті обтрунтовані методологічні підходи у краєзнавчій діяльності, такі як антропологічний, аксіологічний, системний, діяльнісно-особистісний, культурологічний, етнопедагогічний тощя. Розкривається структура краєзнавчих знань: емпіричні (поняття, терміни, факти навколишньої дійсності), теоретичні (закони, теорії, гіпотези).

Ключові слова: професійна підготовка майбутніх учителів фізичної культури, компетентнісний підхід, організація краєзнавчої діяльності, творчі здібності вчителя, освітній прочес, сучасні педагогічні технології.

КРАВЕЦ М. В. Особенности подготовки будущих учителей физической культуры к краеведческой деятельности.

В статье проанализированы различные аспекты профессиональной подготовки будущих учителей физической культуры, раскрыто сущчностное содержсание понятия “компетентностный подход". Отмечено, что основным направлениям реализации компетентностного подхода в подготовке будущих учителей физической культуры к краеведческой деятельности относятся: дидактический, профессиональный, креативный, рефлексивный. На основе анализа научно-методических источников определено, что краеведческая деятельность будущих учителей физической культуры на основе компетентностного подхода - целенаправленная поисково-исследовательская деятельность, цель которой - расширить и углубить краеведческие знания, умения и навыки, развить самодеятельность и творческие способности, удовлетворить интерес $\kappa$ предмету $u$ обеспечить развитие физического и психического здоровья.

Определена методическая система профессиональной подготовки будущих учителей физической культуры на основе компетентностного подхода, которая является сложной, открытой и динамичной. Профессиональная компетентность учителя физической культуры состоит из компетенций, которые наблюдаются, измеряются и иеленаправленно формируются в прочессе образования.

В статье обоснованы методологические подходы в краеведческой деятельности, такие как антропологический, аксиологический, системный, культурологический, этнопедагогический. Раскрывается структура краеведческих знаний: эмпирические (понятия, термины, факты окружающей действительности), теоретические (законы, теории, гипотезы).

Ключевые слова: профессиональная подготовка будущих учителей физической культуры, компетентностный подход, организация краеведческой деятельности, творческие способности, образовательный процесс, современные педагогические технологии. 